\title{
Acute Ischemia of Bilateral Lower Limbs after Femoral Artery Catheterisationin Neonate with Congenital Diafragmatic Hernia (CDH)
}

\author{
Francisco J. Escribá ${ }^{1}$, Jorge Sabater Pavía*2, Pilar Argente Navarro ${ }^{1}$ \\ ${ }^{1}$ Servicio de Anestesia, Reanimación y Tratamiento del Dolor, Hospital La Fe de Valencia, Spain. \\ ${ }^{2}$ Servicio de Anestesia, Reanimación y Tratamiento del Dolor, Hospital de Elda, Alicante, Spain. \\ jsabaterp@gmail.com \\ *Corressponding Author: Jorge Sabater Pavía, Servicio de Anestesia, Reanimación y Tratamiento del Dolor, \\ Hospital de Elda, calle Poeta Artola 4, 46021 Valencia, Spain.
}

4 days neonate, $3 \mathrm{~kg}$, scheduled for thoracoscopic reduction of Bochdalek congenital diaphragmatic hernia. Induction is performed with muscle relaxant. Pulse oximetry and cerebral and regional oximetry are placed. We proceed to ultrasound-guided catheterization of the right femoral artery without incidences, with a 2 French catheter. Within a few minutes, during the positioning of the patient, patchy areas of cyanosis and pallor in both lower limbs begin to appear, and start ascending bilaterally to the upper body.

Due to the rapid establishment of the episode, and the previous administration of the antibiotic, anaphylactic reaction could be the cause, so we requested serum tryptase and histamine which were found negative afterwards.

The main suspicion was vasospasm secondary to femoral artery catheterization, so we removed the catheter, and the signs disappeared within a few minutes. After recovering right perfusion and colour, right radial artery was catheterized and the procedure was performed.

It's important to establish which surgical procedures require more invasive approach in the child. In the described case, the need to perform a goal guided therapy with hemodynamic monitoring using pulse wave analysis (PRAM method) applicable in pediatrics (pediatrics anesthesia study), study of the oxygenation index and modified ventilatory index in the context of a permissive hypercapnia for the perioperative period of $\mathrm{CDH}$, makes mandatory the artery access for our management strategy. ${ }^{1}$

The role of arterial catheterizationin hemodynamic monitoring based on the study of the pulse wave is fundamental ${ }^{2}$.
Among our recommendations in terms of catheter election, weshould look for those with best pulse wave quality for their study and on the other hand those that reports the least complications associated with iatrogenia. Normally we perform ultrasoundguided catheterization, with polyethylene catheter, 2Fsize for the neonates. We choose femoral artery catheterization for therapeutic reasons or invasive hemodynamic monitoring if the radial, the posterior tibial, and the dorsal pedis arteries are not possible.

While ultrasound-guided catheterization of the femoral artery increase the success rate of the cannulation, it probably does not reduce the risk of ischemic complications ${ }^{3}$. Common non-ischemic complications include puncture site hemorrhage, false aneurysm, and arteriovenous fistula. If catheter removal is not enough for reverting the condition, topical nitroglycerin has been used with certain success in some cases to treat vasospasm related to umbilical and peripheral arterial catheterization ${ }^{4,5}$.

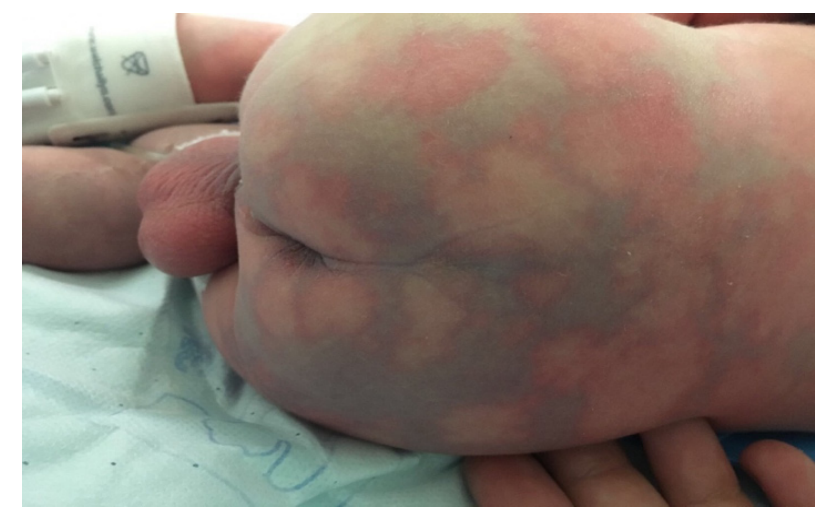

In our case, vasospasm appeared not only in the lower limb where the femoral access was placed, but also in 
Acute Ischemia of Bilateral Lower Limbs after Femoral Artery Catheterisationin Neonate with Congenital Diafragmatic Hernia (CDH)

the contralateral, which could have made it difficult for us to diagnose the cause that triggered the condition.

Neonatal limb ischemia is uncommon, but may have devastating consequences for the patient. Successful management depends on rapid diagnosis. The experience is limited so as to be able to establish clear recommendation strategies.

\section{REFERENCES}

[1] Charles J. Coté, Jerrold Lerman, I. David Todres. A Practice of Anesthesia for Infants and Children 6th edition. Elsevier

[2] Alonso-Iñigo JM, Escribá FJ, Carrasco JI, Fas MJ, Argente P, Galvis JM, Llopis J. Measuring cardiac output in children undergoing cardiac catheterization: comparison between the Fick method and PRAM (pressure recording analytical method).
[3] PaediatrAnaesth. 2016 Nov;26(11):1097-1105. doi: 10.1111/pan.12997. Epub 2016 Aug 27.

[4] Iwashima S, Ishikawa T, Ohzeki T. Ultrasoundguided versus landmark-guided femoral vein access in pediatric cardiac catheterization. PediatrCardiol. 2008 Mar;29(2):339-42. Epub 2007 Sep 13.

[5] Arshad A, McCarthy MJ. Management of limb ischaemia in the neonate and infant. Eur J VascEndovascSurg. 2009 Jul;38(1):61-5. doi: 10.1016/j.ejvs.2009.03.010. Epub 2009 Apr 10.

[6] Vasquez P, Burd A, Mehta R, Hiatt M, Hegyi T. Resolution of peripheral artery catheter-induced ischemic injury following prolonged treatment with topical nitroglycerin ointment in a newborn: a case report. J Perinatol. 2003 Jun;23(4):348-50.

Citation: Francisco J. Escribá, Jorge Sabater Pavía, Pilar Argente Navarro. Acute Ischemia of Bilateral Lower Limbs after Femoral Artery Catheterisationin Neonate with Congenital Diafragmatic Hernia (CDH). Archives of Anesthesiology. 2018; 1(1): 28-31

Copyright: (C) 2018 Francisco J. Escribá, Jorge Sabater Pavía, Pilar Argente Navarro. This is an open access article distributed under the Creative Commons Attribution License, which permits unrestricted use, distribution, and reproduction in any medium, provided the original work is properly cited. 